\title{
David Oliver: There's no dignity in hospital gowns
}

\author{
David Oliver consultant in geriatrics and acute general medicine
}

Berkshire

I've often wondered why on earth we routinely put so many patients into hospital gowns within minutes of their arrival at hospital.

Sometimes referred to as "dignity gowns," such dignity as they afford is only in comparison to being stark naked. They don't come in a wide range of sizes or lengths, and they're open along the back. You tend to get what you're given and make do. The effect is to leave patients with lots of exposed flesh, with underwear or buttocks intermittently displayed and a feeling of extreme vulnerability, not to mention being cold if they have no other layers to wear.

We should bear in mind that patients in hospital-even those attending for planned investigations or procedures-are often anxious and find themselves in an unfamiliar, depersonalising environment. Such fear is multiplied in emergency admissions of people who are already sick and frightened or those with dementia, delirium, or sensory impairment. Such patients are also often in public areas with many other patients and visitors, sometimes of the opposite sex, and they may have to walk out to use toilets or get on to trolleys or chairs and be wheeled down corridors.

There are sometimes entirely legitimate reasons for using gowns-for example, in critical care or surgery or for some imaging or interventional procedures, where easy access to the whole body is vital. But that's not the case for most patients for most of their stay. Yet still we use the gowns, or we keep people wearing them well beyond that immediate need.

In 2010 the fashion designer Ben de Lisi worked with the Design Council to develop a better design, with side fastenings. ${ }^{1}$ But it was never introduced throughout the NHS. More recently, units at some trusts (for example, the radiology department at Leicester teaching hospitals) have used gowns designed for more dignity and comfort. But walk into many places around the country, and you'll still see "old draughty" in widespread use.

\section{Regaining independence}

If you've ever been on a tour of a historical prison you'll have seen descriptions of the arrival process-people having their possessions bagged up and being forced into standard prison clothing, symbolising the transition from citizen to inmate. Surely, we shouldn't replicate this by turning people so symbolically into institutionalised patients. Even if it's just hospital issue pyjamas, we surely want patients recovering from acute illness or surgery to spend more time in day clothes and shoes to help them regain their independence, as emphasised in the "End PJ Paralysis" campaign. ${ }^{2}$

Last year the Lancet published a paper on the impact of wearing gowns, ${ }^{3}$ surveying 928 adult patients and carrying out structured interviews with 10 patients. Over half $(58 \%)$ reported wearing the gown despite feeling uncertain that it was a medical necessity. Gown design was considered inadequate, with $61 \%$ reporting that they struggled to put it on or required assistance and $67 \%$ reporting that it didn't fit. Most worryingly, $72 \%$ felt exposed, $60 \%$ felt self-conscious, and 57\% felt uncomfortable wearing the gown.

Perhaps a starting point would be to use the gowns only in those immediate contexts where they're really required and, even then, to encourage people to wear a dressing gown over them or pyjama bottoms under them. Wherever possible, let's encourage people to be in their day clothes or their own nightwear from home. And yes, a better gown design would help,

Most of all, we as health professionals should be asking why people are wearing them at all.

Competing interests: See bmj.com/about-bmj/freelance-contributors.

Provenance and peer review: Commissioned; not externally peer reviewed.

1 The hospital gown that won't embarrass patients. Telegraph 2010 Mar 24. https://www. telegraph.co.uk/news/health/news/7504037/The-hospital-gown-that-wont-embarrasspatients.html.

2 Skrypak R. End PJ Paralysis Challenge takes NHS by storm. NHS England. 2 May 2018. https://www.england.nhs.uk/blog/end-pj-paralysis-challenge-takes-nhs-by-storm/.

3 Cogan N, Morton L, Georgiadis E. Exploring the effect of the hospital gown on wellbeing: a mixed methods study. Lancet 2019;394:S3210.1016/S0140-6736(19)32829-6.

Published by the BMJ Publishing Group Limited. For permission to use (where not already granted under a licence) please go to http://group.bmj.com/group/rights-licensing/ permissions 
